\title{
ECONOMIC INCENTIVES: SUCCESSFUL IN EXPANSION, WILL IT ALSO BE SUCCESSFUL IN CONTRACTION?
}

\author{
V. BJORNLUND \& H. BJORNLUND \\ University of Lethbridge, Canada and University of South Australia.
}

\begin{abstract}
Since the early 1970s it has increasingly become apparent that the rate of resource extraction is unsustainable. It was also slowly acknowledged that the traditional regulatory approach to resource management proved inadequate to resolve the problem. The use of economic instruments and incentives was proposed as a better way of facilitating the needed change and this has been presented as a policy change, which in many instances have been subject to strong community opposition. In this paper we illustrate how economic instruments and incentives, backed by public investment have been used for more than 5000 years to achieve the objectives of rulers and societies. They are therefore nothing new, what is new is that the policy objective has changed from providing incentives to expand resource use, clear forest, catch more fish, increase water use, and drain wetlands to now providing incentives to reduce resource use, plant trees and recreate wetlands. While expansionary uses of incentives have mainly been seen as positive among resource users and their communities, the new direction is challenging and threatening to both resource users and the communities depending on them as the economic engine for jobs, services and tax revenue.

Keywords: economic instruments, economic incentives, land, water.
\end{abstract}

\section{INTRODUCTION}

Since the start of the industrialization population and economic growth, and therefore the rate and intensity of resources use, have escalated exponentially. Towards the end of the 1960s it became apparent that this rate of resource exploitation was not sustainable. As a result a process of policy change commenced at both national and international levels under the auspices of the United Nation. Milestones in this process were The Stockholm Declaration and Action Plan in 1972, the report of the World Commission on the Environment and Development 'Our Common Future' in 1987, and the Rio Declaration and Agenda 21 in 1992. The latter two document place emphasis on the use of economic instruments and incentives for the management of water and other natural resources as a key component of achieving sustainable development. For water this development was also said to represent a shift from water being considered a social good to an economic good reflecting an acknowledgement of the scarcity of these resources and the environmental impact of their extraction.

Threating water and other natural resource as economic goods and the use of economic instruments was presented as a major shift in policy direction, as if it was something new. In the context of water management this perceived policy shift has generated heated debate and in some instances social unrest. Many are opposed to considering water as an economic good and many are concerned over environmental and socioeconomic impacts of the use of economic instruments. In this paper we argue that there is nothing new in treating these resources as economic goods or the use of economic instruments to achieve policy objectives from their use, rather, this has been the case for the last 5,000 years. While many of the policy objectives pursued by economic instruments in the past were social in nature, what is new is a shift in the social values of societies and therefor a shift in what these instruments are trying to achieve [1]

Throughout history economic instruments have been used to encourage resource users to behave in a way consistent with societies' objectives; until very recently this has meant to increase resource extraction and an intensification of their use. Clear more land, extract more water, fell more trees or 
catch more fish. These are expansionary objectives which most resource users find it easy to align with as they increase their opportunity to create wealth. Resource dependent communities i.e. fishing villages, irrigation districts, and forestry communities also find it easy to accept such policies as resource extraction constitutes the economic engine of the region generating social benefits such as jobs and community prosperity. The use of economic incentive has been very successful and we are today faced with managing the accumulated impact of the deforestation, soil erosion, water logging and other environmental degradation caused by this success

Saying that resource users always have supported these policies would be an overstatement. There are many examples of existing resource users trying to stop the issuing of new permits for resource extraction, as they see continued expansion as a threat to their future livelihood. In many instances government and policy makers ignored such pleas as the prevailing community view was that increased resource use was in the best interest of the society. Some examples are petitions for trawling ban in 1376 in England [2], tobacco producers in Virginia in 1662 arguing for more sustainable farming practices [3], the call for limiting the catch of lobster and the number of fishermen in Main [4], salmon fishing in Europe [5], ground water irrigators in the Namoi Region of New South Wales, Australia [6] and protection of sprawling grounds by coastal cod fishermen in Newfoundland, Canada [7].

In an attempt to reduce resource extraction and improve environmental conditions today's policy makers have again turned their attention to the use of economic instruments. However, the objectives are now reversed trying to reduce resource extraction to produce desired environmental and social benefits and to ensure the highest value output from the scarce resources. Many resource users and their communities do not favour this change as it challenges the current economic and social structure, raises issues of stranded community assets, and threatens the value of the resource users' assets, their livelihood and in general the viability of their community.

In the first parts of this paper we demonstrate how previous societies since Babylonian times around $3000 \mathrm{BC}$ have been in similar situations. They were largely unsuccessful in dealing with these impacts resulting in the decline and eventual collapse of some societies. In the following parts we discuss more recent use of economic instruments in Europe, North America, Australia and the Indian Subcontinent. It is the environmental consequences of these policies that we are trying to deal with today with the next generation of economic incentives. The verdict is still out on the ability of today's society and its policies to deal with these consequences.

The focus of the paper is to illustrate how water and land have been treated as economic goods and how economic incentives have been used to direct their use to achieve the political and social objectives of the time. Our objective is to use history to illustrate the confusion in the current debate over the status of water as a social or economic good and that the use of economic incentives and instruments somehow should influence this status. We aim to illustrate that the conflict is over a shift in what today's society define as its social objectives and how regulation and economic instruments need to be combined to secure social and environmental objectives which market forces alone cannot achieve.

We want to emphasize on the outset that our focus is on the impact of human behaviour, we are aware of the debate over the human-environment-climate interaction and do not dismiss that this interaction is at play in the examples provided, and we make reference to that in the text. However, we have chosen examples where there is little doubt in the literature that the human impact is of paramount importance, and focus on these aspects.

\section{THE EARLY AGRARIAN SOCIETIES: MESOPOTAMIA - AN EXAMPLE}

In the early stages of irrigation in Mesopotamia water tables was controlled by avoiding excessive irrigation and by fallowing land in alternate years. This allowed the deep-rooted natural vegetation to dry out the top layer of the soil and prevent the rise of salts through capillary action to the root 
zone of the crops. In extreme cases, longer periods of abandonment must have been a part of the agricultural cycle. Through evapotranspiration and slow draining they could eventually reduce an artificially raised water table to safe levels [8].

As these societies grew and competition among them for land resources intensified the rulers needed armies to protect the state and enable its expansion [9]. The rulers needed to secure loyalty from the armies and the most influential families. This loyalty was often secured by granting the leaders of the armies and the most influential families, large areas of land, access to irrigation and a supply of slaves captured in the wars [10]. They were in effect given as economic incentives to secure loyalty and to secure food supply, the economic and social policy objectives of the society at the time.

Soldiers of the armies were conscripted among free men who could be required to serve for lengthy periods and often did not return. This resulted in increased pressure on land and water resources for at least two reasons: First, it created a class of absentee landlords which farmed their land with slaves and overseers with little long term interest in the productivity of land and hence introduced unsustainable practices for short term gain. Second, it increased the need to raise tax revenue to fund the armies. In response food production was intensified, fallowing of irrigated land was abandoned and the area under farming was expanded, often resulting in deforestation, and the construction of major irrigation structures which enabled continued or multiple cropping [11].

In Mesopotamia this process resulted in the disappearance of a thriving culture. Deforestation in the upper reaches increased the silt load in the Euphrates choking the canals. The poor permeability and drainage capability of soils in combination with the introduction of continued irrigation caused water logging and brought salt to the surface.

Detailed records provide evidence of changing agricultural production and declining yield as these conditions worsened. The records suggest that '(a)round 3,500 BC roughly equal amounts of wheat and barley were grown in southern Mesopotamia. By 2,500 BC wheat had fallen to only $15 \%$, by $2100 \mathrm{BC}$ wheat production was abandoned in Ur and had declined to just $2 \%$ of the crops grown in Mesopotamia' [12, p. 1952]. The same period also saw a serious decline in fertility which for the most part can he attributed to salinization which also accounts for the shift from wheat to barley as the latter is more salt tolerant. At about $2400 \mathrm{BC}$ average yield was 2537 kilos per hectare - respectable by modern United States and Canadian standards. This figure had declined to 1460 by 2100 BC, and by about $1700 \mathrm{BC}$ it had shrunk to an average of 897 [13].

As the productivity of land declined economic instruments in the form of penalties associated with farming were needed to fight the decline and keep people on the land. The first comprehensive written law the Code of Hammurabi in $1784 \mathrm{BC}$ introduced heavy penalties for neglecting irrigation infrastructure and thereby causing damage or loss to other farmers, and if farmers left their land idle for too long, the owners forfeited their right to the land [12].

The effects of this slow but cumulatively large decline must have been particularly devastating in the cities, where the needs of a considerable superstructure of priests, administrators, merchants, soldiers, and craftsmen had to be met with surpluses from primary agricultural production [12]. The policy measures taken were obviously inadequate as eventually this thriving society collapsed and large tracts of the land have still not recovered.

\subsection{The Roman Empire}

The economy of the Roman Empire was agrarian. In the process of building their Empire the Romans gathered experiences from various part of the Empire. Engineers learned about aqueducts from Syria, water wheels from Persia, water lifting devises from Egypt and in that process greatly expanded technological knowledge [14]. 
Early Roman farmers used intensive farming practices with diversified fields being hoed and weeded manually and carefully fertilized. The earliest Roman farmers planted a multistory canopy of olives, grapes, cereals, and fodder crops. Inter-planting of understory crops helped to control weeds, save labor, and prevent erosion by covering the ground all year round [15].

To facilitate the expansion of the Empire many financial and human resources were absorbed by the armies. To finance this process, farmers were heavily taxed. In order to pay these taxes they exploited the land intensively. This contributed to serious soil erosion and land degradation [3]. This problem was exacerbated by the fact that many farmers were required to serve as soldiers in the armies leaving the land in the hands of slaves and overseers with no long-term interest in the land [16].

Other economic incentives encouraged small farmers to leave the land and move to Rome. For example, only people living in Rome could vote, and votes could be sold, and citizens of Rome could buy grain at half the market price or less and later grain and other foods were given for free. Since senators were forbidden to participate in commerce many invested in large landholdings on state land on which they paid only a nominal rent. This group of absentee landowners further degraded the soil in pursuit of quick profit [17]. These processes resulted in land consolidation and by year zero huge estates accounted for nearly all the arable land within two days' travel from Rome.

The total area under Roman cultivation continued to expand and the land fared poorly under these vast farming operations and in response large areas of farm land was abandoned [14]. In an attempt to remedy this problem new economic incentives were introduced. In the 2nd century AD abandoned farmland was offered to anyone willing to work it for two years but few took advantage of the offer. A century later free farmers and slaves were forced to stay on their land and sons of farmers were prevented from leaving the farm.

Driven by declining agricultural production due to soil degradation and the continued and increasing need for food to feed the armies and the citizen of Rome, the Roman Empire, tried to increase their agricultural production overseas. It conquered provinces and enslaved the local peasants to work on land granted to syndicates of wealthy citizens living in Rome. This land was granted as an economic incentive to maintain loyalty to the emperor and to secure food production for the roman armies. Local nobility could keep their assets if they switched their loyalty to Rome. Roman soldiers were given rewards at the end of their service including cash, land and cheap labor or slaves as an economic incentive to stay in the army [18].

The aim of the owners of these farming operations was to make quick profits from the supply of grain to Rome. To achieve this they concentrated on the main grain crops demanded while spending little on fertilizer and other inputs. The land was so fertile that productivity was kept high for centuries. By the first century AD Rome was extracting half a million tons of grain a year from North Africa. As the Romans expanded farming into ever more marginal lands, the displaced local farmers moved into even more marginal land and even into semi-desert areas. This process pushed nomadic or semi-nomadic pastoralists towards the Sahara causing further soil degradation. This chain of events contributed to widespread degradation and started a desertification process. The North African coast produced bountiful harvest until the desert eventually began encroaching from the south [18].

When output began to fall the Roman officials initially considered it to be an attempt of tax evasion and responded by introducing tougher methods of tax collection. Farmers' response to declining fertility was to plant olive trees which are drought resistant and produce on poorer soil. In response the government tried to place a ban on olive to retain wheat production. However, as it became obvious that the only thing that could be produced was olives and dates, the ban was removed [18]. 
It has been contested that this degradation and desertification was driven by a drying climate. However, extensive studies [19] concluded that the climate has remained stable over the last 3000 years and hence climate change cannot account for change.

\subsection{The Islamic Empire}

During the spread of the Islamic Empire in the 7th and 8th century A.D. a new agricultural revolution took place spurred by demand for better cotton, better and different food and new medical plants. Land became scarcer and less fertile; areas, with less hospitable climates, were taken into production. However, agricultural science made significant advances in the understanding of different classes of soil. More capital and labour were applied to each unit of land which therefore created a more stable and higher income for all farming categories. This was an economically rational response to growing land scarcity and to increasing availability of labour and capital [20].

To encourage these changes the state introduced economic incentives in the form of lower rates of taxation on certain land and products. Taxes were usually $1 / 10$ or 1/5 depending on the status of the land or its owner. Reflecting the objectives of the state, fruit and vegetable productions were either not taxed or was levied a lower tax. Some authors argue that the same was the case for sorghum and cotton. Similarly, farmers who invested in water lifting devises such as the Shaduf or the Noira wheel to expand irrigated production were also taxed more lightly. On the other hand strong penalties were in place to prevent agricultural land from being left idle. For example if a farmer abandoned cultivatable land the state could take possession and transfer it to a new farmer, and special taxes were levied on uncultivated land which could be irrigated [20].

This low taxation regime was one of the factors which maintained a class of smaller, independent farmers avoiding the problems associated with large absentee landowners so prevalent in Rome, Mesopotamia and other ancient societies [20].This is thus an example where the political objectives of the use of economic incentives were to intensify land use and increase productivity rather than to expand the area in farming, or expand into new geographical regions.

\section{CHINA UNDER THE SONG DYNASTY (AD 960-1279)}

The Emperors and their bureaucracies under the Song Dynasty thought of agriculture as an important source of revenue. They therefor invested heavily in land reclamation, irrigation, the development and dissemination of new farming technologies and seed varieties to increase the productivity of land in existing farm regions. To ensure farmer participation significant economic incentives were introduced for peasants to increase productivity, and bring new barren land into production. This resulted in a threefold increase in crop production [21].

Encouraged by economic incentives peasants increased the area under farming by more than two million hectares during the first two centuries of the Song Dynasty. Incentives used included: i) land grants in new regions; ii) ownership of new farmland in existing valleys created by terracing the hillsides; iii) improved access to water; and iv) tax waivers on irrigated land.

Increase in productivity was encouraged by: i) government loans for draft animals; ii) public investment in agricultural engineering innovations for irrigation and drainage as well as farm equipment such as the East River plough, which allowed for flexibility in the depth of furrowing; iii) introducing new seeds such as high yielding paddy rice varieties from Korea, and quicker ripening rice-varieties from Vietnam which facilitated double and sometimes triple cropping; iv) waving taxes on the second crop encouraged double cropping; and v) local governments involvement in commercial fertilizer operations using organic matters such as night soil, manure, ashes, and 
compost. Knowledge about these practices and techniques were promoted through technical advice and the distribution of agricultural handbooks etc. [21,22].

Irrigation was also greatly promoted during this period. A new Law and Decree on Irrigation was introduced in 1069 encouraging expansion of irrigation systems. By 1076, about 10,800 irrigation projects were completed, irrigating more than 2.4 million ha of public and private land [22].

\section{PERMANENT SETTLEMENT OF MONGOLIA AND THE FRONTIER PROVINCES}

Changing Chinese emperors have also used economic incentives to encourage settlement of frontier region to achieve political goals such as increasing farm production and securing frontier regions by introducing loyal Han Chinese and thereby change the composition of the population.

The Mongolian steppe has a very dry climate and a very fragile environment marked by extreme variability in temperature and precipitation. Temporal use of the grassland by mobile pastoralists has been adopted to maximize the use and benefits from this environment throughout history [23]. Cultivation of the steppe in Inner Mongolia took place during three periods of extensive settlement.

It started during the Han Dynasty (206 BC-220 AD) when the policy of settlement in the frontier region was introduced. As a consequence a large area of grassland and forest was converted to crop production. A second period of expansion of cultivation took place in the late Tang (618-907 AD) and continued during the Song (960-1279 AD), when the military converted land into cultivation and encouraged settlement to reinforce the defence of the frontier and creating a tax base. The third period took place during the last half of the Qing Dynasty (1616-1911 AD) culminating in the late 1820 s when a policy was introduced to establish the western regions as a province by encouraging the immigration of Han Chinese to drive further agricultural expansion into native grasslands [23].

Common for these large scale frontier settlements was that they were part of military defense schemes to secure the frontiers and increase revenue to fund the armies. The new settlers were either soldiers or peasants escaping from natural hazard. If the settler was peasant, the cultivated land was owned mostly by the state with the harvest shared equally between the state and the peasant or sometimes 40-60; or 60-40\% if the peasant also got a draft animal [24].

Each of the three periods of extensive expansion of cultivation was followed by land degradation caused by soil erosion as spring tilling coincides with periods of intensive wind and subsequent cropland abandonment with nomads gradually reclaiming the degraded area. This system worked as long as there was enough sparsely populated grassland for people to migrate to so that the land degraded by intensive cultivation could recover.

The conversion from grassland to cultivated land has created surface sand-dust from which sand storms are created. Sand storms and desertification reinforce each other. Frequent sand storms increase desertification while the degraded grasslands and exposed top soil provide sand-dust to fuel the storms [25]. As a result the frequency of storms has increased from one every 31 years from 300 to $194 \mathrm{AD}$ to one every two years between 1950 and 1990 . Since 1990 there has been one almost every year. Over the past 30 years an average of 35-50 tons of soils have been lost from each hectare of cultivated land. Today, half the cultivated land in Mongolia is considered to be degraded to some degree [26]. Damage caused by sandstorms costs about $\$ 540$ million per year, while the cost of the 'green wall built to shield Beijing is estimated at $\$ 6$ billion [27].

\section{WESTERN EUROPE AND THE NORTHERN CRUSADES}

Following the collapse of the Western Roman Empire no rulers were able to guarantee security to the farmers of Europe. Instead, kings and emperors vested control of land in the churches and local lords 
as an economic incentive to establish order and protection at the local level and provide revenue and soldiers to the rulers [28].

By the 11th century a feudal law and order system had been established in Western and Central Europe with the Church and feudal lords in control of the land. From the 11th to 13th century, the cultivated area quadrupled; this was driven by improved agricultural practices, the use of animal power and the desire of the feudal lords and churches to expand their agricultural production. The improved technologies made it possible to clear and till the heavier forest soils of Northern Europe and drain swamps. To encourage this process many feudal lords granted serfs their freedom and parts of the land they helped clearing or draining. This process caused the biggest transformation of natural vegetation in Europe since the Ice Age [28].

The northern crusades were part of this process which resulted in 150.000 to 200.000 peasants from the west colonizing Prussia and what today constitute the Baltic States (Fig. 1). This area became the bread basket of Europe and allowed farmers in Western Europe to concentrate on high value crops for the growing cities and the emerging industries. To encourage the settlement of the new areas peasants of Western Europe were given their freedom and granted some of the concurred land [29].

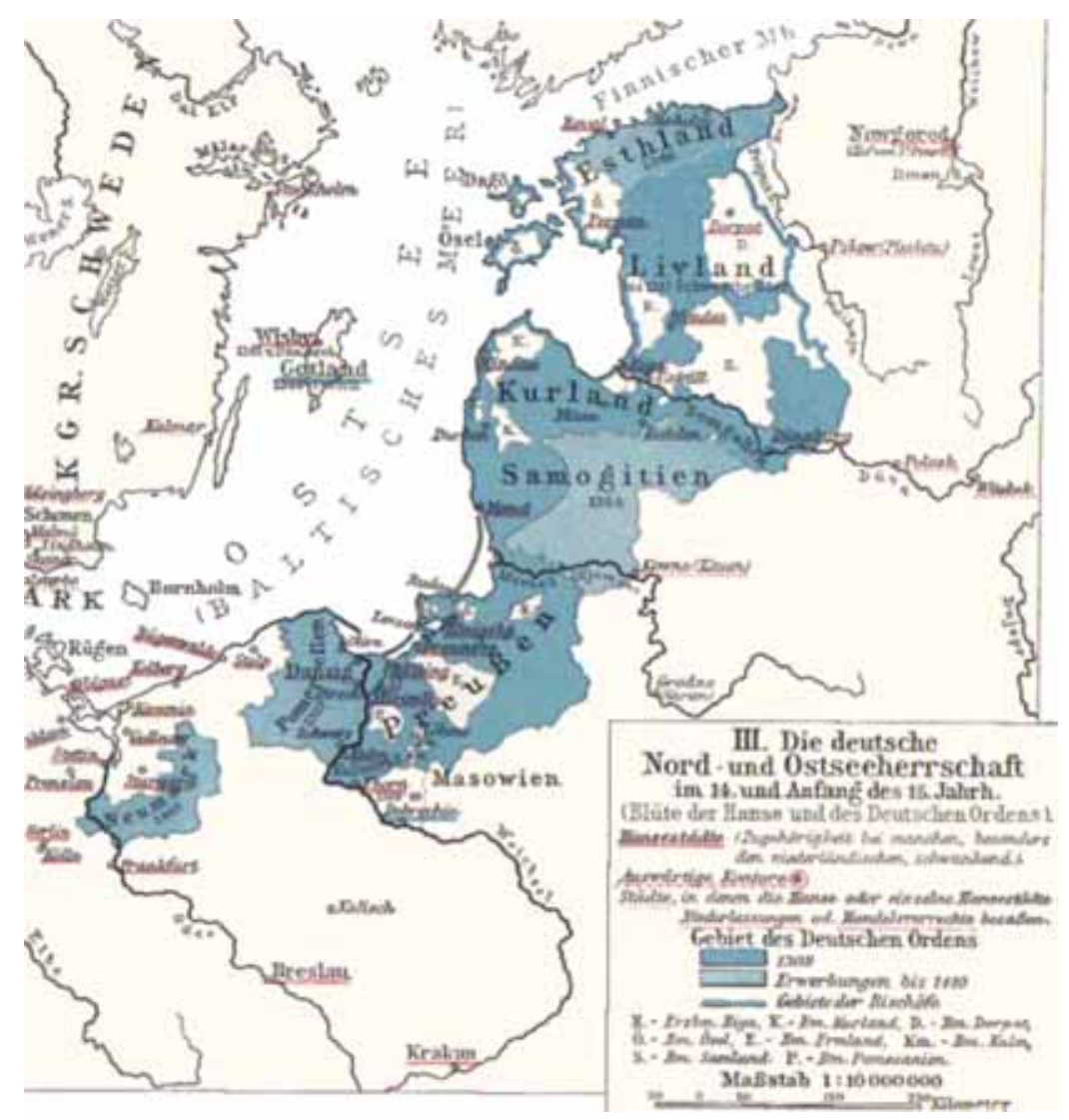

Figure 1: The Baltic Colonies: suppliers of raw material (Source [29]). 


\subsection{The Americas}

Industrialization increased demand for raw material such as cotton and consumer products such as coffee, tea and tobacco. To continue expansion, Europe started to establish colonies. As an economic incentive to secure investments, the British monarchs granted companies extensive charters including control over land and trading concessions. For example the Charter of the Virginia Company of London was established by royal charter in 1606 to establish colonial settlements in North America. Similarly, the British East India Company was granted a Royal Charter in 1600 giving them control over the Indian Subcontinent ranging from Pakistan to Burma [30] and the Hudson Bay Company received a Royal Charter in 1670 giving them control over Rupert's Land covering most of today's Canada [31]. This started a process of resource extracting economic policies on scales hitherto unseen and with environmental and social consequences that current generations are struggling to deal with.

The colonization process intensified in the15th, 16th and 17th century into South and North America. Free access to land and cheap labour were economic instruments used by the colonial power to encourage settlement and the production of agricultural products. In South and Central America the Spanish government granted permission to use local labour as slaves to promote mining and agriculture [32].

The British initially used free access to land and provision of cheap indentured labour as economic incentives to increase production in the new colonies. People not able to pay their debt in England were sent to the new world to work for seven years to pay their passage. This initially supported the tobacco industry which soon became the biggest source of revenue for the English Crown. The incentive of free access to land caused the tobacco growers to abandon land after four to five harvests as it was then totally depleted of nitrogen and phosphorous and eroded due to the farming practices used. It was much cheaper to move to new virgin land than applying fertilizer and changing management practices. Some farmers proposed the introduction of conservation farming practices to sustain agricultural production but the English government discouraged this as it would reduce productivity and tax revenue [3].

As a result about 50 million acres of good farm land in the United States have been ruined for further practical cultivation [33]. To secure a continued flow of cheap labour, and to resolve the problem of overflowing prisons in England, convicts were transported to North American, 50.000 from 1718 to the end of the War of Independence in 1776 [34].

After Independence the new nation sought to expand agricultural production outside the original 13 colonies. As an economic incentive to facilitate this process the Homestead Act was passed in 1862. Under this act anybody could apply for freehold title to 160 acres of land. To eventually get freehold the applicant must live on the land for five years and improve it (clear native vegetation and till it). This opportunity was a significant lure for many poor land strapped European peasants. By the turn of the 20th century the better more productive land had been taken up.

The Enlarged Homestead Act was therefore passed in 1909 and the Stock-Raising Homestead Act in 1916. The purpose of these acts was to encourage the settlement of the poorer soils suitable for dry land farming and grazing. Under these acts applicants could claim 320 and 640 acres respectively. It was the impact of land clearing and tilling of these poorer soils which caused the dust bowl of the 1930s and the associated hardship [35]. Only about 40\% of the applicants starting the process of getting freehold succeeded.

In the dry parts of the American West irrigation was necessary to support agriculture. Irrigation was developed by private canal and ditch corporations. From 1890 to 1900 the area under irrigation increased from 1.5 million acres to 6 million acres. However, these often failed due to lack of funds 


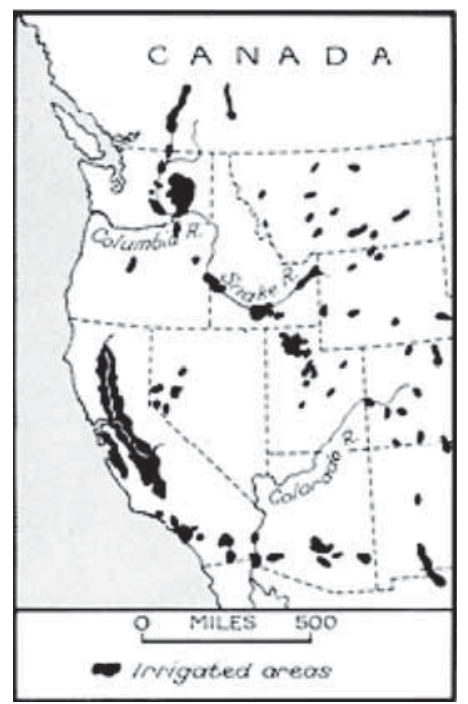

Figure 2: 30 irrigated projects developed from 1902-07 in the western United States (Source [36]).

and engineering skills. Following extended droughts in the 1890s pressure mounted for the government to fund major storage and irrigation projects [36].

This resulted in the Reclamation Act, 1902. The rationale for government investment was that irrigation would reclaim land for settlement and increase food production. From 1902 to 1907 the Bureau of Reclamation began some 30 projects in Western states putting 2.6 million additional acres under irrigation (Fig. 2). The land and access to water was granted to farmers under favorable conditions. Many of the early projects encountered problems as the land was not suitable for irrigation and could only grow low value crops and land speculation resulted in poor settlement pattern. Further, farmers were inexperienced in irrigation resulting in water logging and reduced productivity. Given the relatively high cost of land preparation and construction many projects could not meet the payment schedules. As late as the 1930s, federal reclamation had not really succeeded, it had merely survived with numerous bailouts by government [36].

Intensives irrigation generated its own social and environmental impacts. From its inception, the Bureau of Reclamation operated much differently than its founders had envisioned. Very few irrigation projects were actually paid for by their beneficiaries; hence, they quickly became economic subsidies or incentives. The proliferation of modest homesteads that had been the reason for placing the responsibility for irrigation in the federal government never eventuated. Land speculators bought much of the land where they anticipated dams would be built, and the bureau showed little interest in enforcing its 160 -acre limit. In most projects, it was actually impossible to purchase small tracts of land. The high productivity and costs of irrigated lands meant that such agriculture tended to be more market-oriented, more mechanized, and to employ more migrant labour than elsewhere. In practice, irrigation helped to solidify the dominance of large-scale agribusiness in the West [37].

Environmental problems have increasingly limited the effectiveness of irrigation and reduced its public support. The damming of most of the West's major rivers has destroyed salmon runs and river flows have been dramatically altered. Salinization, caused by perpetually water-logged soils, puts thousands of acres out of production each year [37]. 
In a similar way the Canadian government had great desire to settle the Western frontier and establish railways into the West. By 1872, the government had purchased the land belonging to the Hudson Bay. As an economic incentive to attract settlers to open up the country and make possible the building of railways, the government began advertising grants of free land in the West. Free homesteads of 160 acres were granted to farmers on the condition that they clear ten acres and build a house within three years. As in the US the government eventually invested in major irrigation infrastructure and offered irrigation water as an incentive to settle the arid regions of Alberta [38].

\subsection{Australia and New Zealand}

Following the War of Independence in the American colonies Britain lost a source of important raw materials as well as a place to deposit convicts. It therefore showed an increased interest in gaining a foothold in the Pacific and East Asia as a base for its growing interest in this region. Also the prison population started to mount again due to the loss of the American colonies and continued harsh social and economic conditions in the major cities. In 1787, Britain therefore established a penal settlement in New South Wales. To ensure that the new settlement would be self-financed the Government granted large areas of land as an economic incentive to members of the British nobility and supplied them with cheap convict labour with 150.000 being transported to Australia between 1787 and 1840 [39].

The settlement of Australia by voluntary settlers was spurred on by a general economic collapse in Britain after the end of the Napoleon wars. A mixture of factors caused an economic depression. Government coffers were empty after a long period of wars. The labor market was flooded with returning soldiers and sailors as well as workers made redundant due to mechanization of agriculture and industrialization in the cities. This caused a high rate of unemployed and escalating expenditures on poor relief. Cities were filling with hungry unemployed people living in very poor conditions creating discontent and rising crime rates. The ruling class in Britain concluded that the country had a surplus population while its overseas colonies needed people [40].

People were encouraged to emigrate to Australia and New Zealand ${ }^{1}$ by various economic incentives such as offers of cheap and financed travel and favorable land purchases or land leases. However, these were, as in the United States and Canada, under improvement conditions. Failing to clear and till the land constituted breach of the lease conditions and loss of the land [41]. Land clearing was supported by the Commonwealth and State Governments as it was seen as an essential part of improving productivity and securing prosperity.

A range of economic incentives for agriculture were introduced in order to increase the attractiveness of land clearing such as cheap land along with venture capital in the form of loans or tax concessions. Other incentives included the War Service Land Settlement Scheme, low interest bank loans and financial support programs such as drought relief. These processes fueled a rapid land clearing process generating serious land degradation with raising water table and dry land salinity, $800.000 \mathrm{Ha}$ of agricultural land are now unsuitable for any agricultural use. Extensive clearing for agriculture occurred in the 1960s and 1970s, and is still taking place. Particularly in the 1950s and 1960s, significant tax concessions existed for land clearing [44].

The spread of agricultural production to more marginal and fragile land was also encouraged by two other economic incentives, the wool and the wheat schemes which provided guaranteed markets and prices and fertilizer subsidies. This pushed wheat production into areas not really suitable for

1. A similar scheme was available to settle the Cape Colony of South Africa under the Cape Emigration Scheme of 1820 [42, 43]. 
permanent cropping and increased stocking rates of sheep on fragile lands with severe long term impacts [45].

During the 1860's and 1870's settlement along the Murray River intensified. The combined impact of the drought from 1877 to 1881 and a fall in wheat prices encouraged dryland farmers to look for alternative land uses. The interest in irrigation increased to provide a cushion against drought and a greater flexibility in crop choices. Initially irrigation projects were private ventures aiming to combine irrigated and non-irrigated lands in order to support relatively extensive farming mainly relying on rainfall. However, these early projects could not support themselves and failed financially. It became apparent that to make irrigation profitable intensive irrigation was needed [45].

Economic depression of the 1890's and the Federation drought between 1897 and 1902 spurred the government to invest in large scale systems for intensive irrigation. This was made possible when new state water acts were introduced commencing with the Victorian Water Act in 1886 vesting ownership and control over water in the crown. This provided cheap water for irrigators facilitating more intensive and higher value productions such as dairying and fruit growing [46].

This was part of a closer settlement policy to encourage population of the dry areas of the interior. This process was hindered by the fact that not enough farmers applied for irrigation blocks. In response the government sent a delegation overseas and advertised in Europe and North America for settlement in Victorian Irrigation Districts (Fig. 3) [46]. This started the process of immigrant settlement which in turn increased the take up of irrigation among Australian farmers. After World War 2 the settlement process gained further momentum with soldier settlements where returning soldiers were granted land and water in newly developed irrigation districts as a financial reward [47].

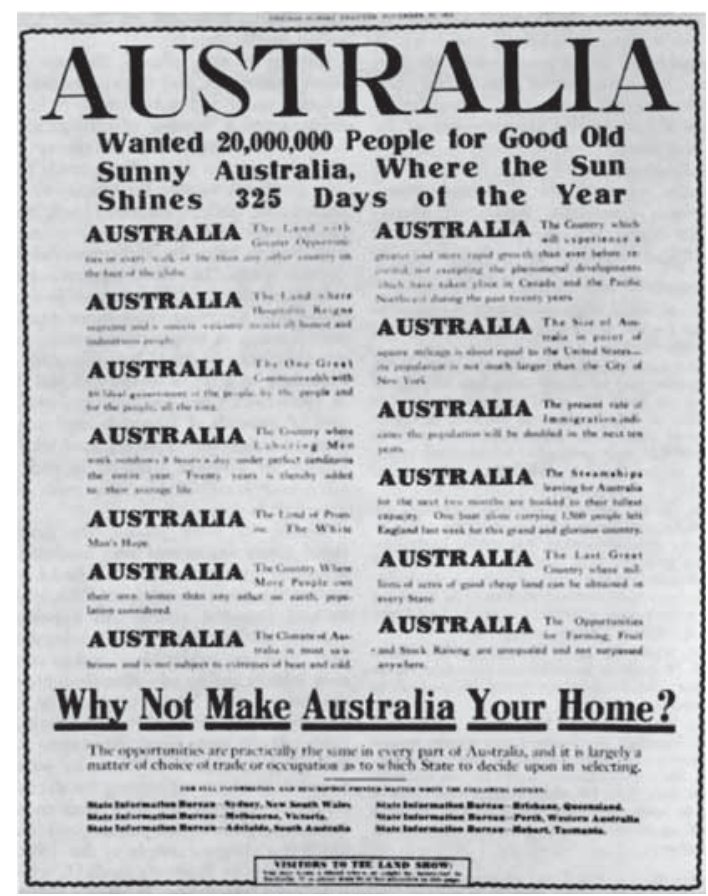

Figure 3: Add placed in Chicago Sunday Examiner for November 19, 1911. (Source [46]). 
The process of Dam building continued up until the 1980s. In Victoria most of the new water was used to increase the water available to existing irrigators at no cost to them. The purpose of this was to facilitate a transition from irrigation as drought protection to fully support irrigated production. This resulted in a rapid expansion and intensification of irrigation, largely driven by substantial government economic incentives in the form of free water and land and was associated with a number of problems: i) many projects were established without proper soil and hydraulic surveys with the result that some areas suffered from raising water tables and salinization within a very short span of time; ii) some states continued to issue new water licenses so that eventually most resources in the southeastern part of Australia was over allocated; and iii) access to cheap water resulted in inefficient water application exaggerating the environmental problems [47].

The Australian Government finally started to wake up to these realities in the later 1980 and in 1994 introduced a new water policy framework starting to reverse the direction of economic instruments and incentives. As part of this process water markets were made compulsory in all states, land and water rights were separated, irrigation infrastructure was transferred to the irrigators and privatized; full cost recovery water pricing was introduced; and the environment was recognized as a legitimate water user [48].

\section{IRRIGATION-SCHEMES ON THE INDIAN SUBCONTINENT}

The Indian Subcontinent has 5-6 thousand years of irrigated agriculture with tanks, inundation canals, temporary bunds to trap drainage water, wells and water-wheels used to harvest water. These techniques were essentially directed towards impounding precipitation, tapping river inundations or retrieving groundwater recharge. These methods were designed to suit the local micro-climates, topography and hydraulic conditions. In the early 19th century the British initiated a radical break in both technique and hydraulic principle by introducing perennial canal irrigation in several parts of the subcontinent [49]. These systems were often superimposed on and therefore destroyed existing irrigation infrastructure.

An example of this is the decline in traditional tank irrigation in southern India which has a long history of rainwater harvesting using tanks and supporting a vibrant agricultural community in this semi-arid region. Prior to the arrival of the British, people at the village level took responsibility for maintaining irrigation works. The economic instrument used by the British broke this tradition. The interest of the British government in increasing public investment in irrigation was to gain higher revenue, and in the pursuit of high returns/profits totally neglected the maintenance and development of the minor traditional local irrigation works.

In pre-British India taxes were $1 / 8,1 / 10$ or $1 / 12$ of the produce depending on the type of soil and the extent of labour required to cultivate it. Hence the tax was related to the ability to pay. While the British imposed lower taxes on dryland than irrigated land, all land that had the potential for irrigation had to pay the higher taxes, weather there was enough water in the tank or not. Hence payment of taxes was not related to production and the ability to pay [50].

Further, prior to the arrival of the British villagers maintained their own irrigation works and there were no charges for water. This system was eventually changed so that water charges were levied even from the tanks maintained by irrigators. The Government contributed to the maintenance of major tanks fed by canals but not to minor tanks. The consequences of the changes to the tax regime, water charges and maintenance were that much land was out of cultivation, communities were impoverished and land was rapidly concentrating in the hands of moneylenders [51].

As an economic incentive for the construction of canal irrigation it was designed to provide an investment opportunity for British capital and policies for their use was therefore designed to secure the revenue necessary to service this capital and deliver produce to meet British needs. The era of 
modern irrigation witnessed the construction of several large canal irrigation schemes with permanent head-works such as Ganges (1854), Godavery (1852) and Krishna (1855) [52]. These large projects facilitated a dramatic increase in cropping intensity, growth of commercial farming and the spread of mono-cropping. When the production increases began to level-off early in the 20th century, salinization and water logging had turned large areas of fertile and cultivated lands into barren wastelands [53].

This impact was amplified after independence as the government was committed to the new infrastructure and promoted its use through a set of subsidies which made it more viable for the farmers to use the new systems than maintain the old systems. This happened in a number of ways: i) subsidies for electricity supply making it cheap to pump water from dams via canals or from tube wells deep in the ground; ii) subsidies for fertilizer which made farmers less dependent on the use of tank silt as production enhancing material; iii) subsidies for water from dams reduced the dependence on tanks; and iv) subsidies for diesel pumps reduced the dependence on water from tanks [54].

During the Green Revolution high responsive varieties of wheat and rice were introduced. These varieties required a very intensive use of irrigation, fertilizers and agricultural chemicals. The Indian Government heavily subsidised agricultural input such as water, fertilizers, electricity, and credit. This quickly resulted in soil degradation due to over-use of fertilizer, irrigation induced salinity, and depletion of groundwater to the extent that, at the turn of the century, one million hectares suffered from irrigation induced water logging and salinity in northwest India alone [55].

As a result of subsidies for pumps and electricity combined with poor and ineffective management of irrigation canals groundwater pumping is now the preferred method of irrigation. Groundwater tables are therefore falling dramatically with serious economic impact. Where a $3 \mathrm{Hp}$ pump could supply water for 14 acres of cotton in 1973, it takes a 15 Hp pump to draw water from 20 meters down to water the same lot in 2009 [56].

The government also introduced minimum support prices for some of the major agricultural products such as rice and wheat as an incentive to make the investment in infrastructure and input required to produce these crops. However, there is evidence to suggest that this has not resulted in farm investments but has drained the government's coffers so no funds are available for soil conservation programs or to address the issue of crop/water efficiency [57].

\section{USE OF ECONOMIC INCENTIVES FOR THE CONTRACTION OF RESOURCE USE}

The use of economic incentives to reduce resource extraction started before the Rio Declaration and Agenda 21 in 1992. Since the early 1970s, policy makers became increasingly receptive to market oriented instruments to manage environmental and natural resources [58]. Variants of markets were successfully introduced in the US during the 1970s to control local air pollution, during the 1980s tradable permits were used to phase out leaded petrol and ozone-depleting chlorofluorocarbons; and in the 1990s an allowance-trading program was used to cut national emission of $\mathrm{SO}_{2}$ by half of the 1980 level before 2000. Within fisheries, tradable permits have been seriously considered since the 1950s [59] and actual tradable systems were introduced in British Colombia in 1968 [60], in Iceland in 1979 [61] and in New Zealand in 1982 [62]. Water markets emerged as a mean of reallocating water between competing users and to meet new demand within closed systems in Australia in 1984, Chile in 1979 and in the Western US in the 70s and 80s [63].

After 1992, markets have been introduced in many other areas such as wetland off-sets in the US [64], water quality in the US and Australia [65, 66], native vegetation off-sets in the US [67, 68] and manure credits in Holland [69]. More recently water markets in the US and Australia have been used by governments and private organizations to buy water entitlements to secure environmental outcomes [70, 71]. 
It is outside the scope of this paper to discuss any of these markets and economic incentives in depth. Suffice it to say that the results are mixed. In many instances such as the Dutch manure market and the California RECLAIM program, resource users at the time of introducing tradable right were able to obtain very large rights as they were based on the resource users' statement of prior use, which they naturally overstated $[69,72]$. As part of the air pollution trading program under the US Clean Air Act, stationary polluters could purchase credits created by scrapping old polluting cars, however it has been argued that while the body of the car was scrapped many of the polluting engines were sold and thereby continued to pollute [72].

The wetland and forest off-set programs as well a water pollution credit programs and $\mathrm{CO}_{2}$ trading programs have had their problems caused by lack of enforcement of the programs, lack of compliance, inability of created wetland $[68,73]$ and forests [68] to survive and provide the same ecosystem functions as the destroyed areas, and the uncertainty associated with the long-term capacity of newly planted forests to continue to off-set the $\mathrm{CO}_{2}$ emission [74].

The most successful programs have been the so-called cap-and-trade programs [75] under which total resource use is capped and trade is then allowed in extraction rights under this cap. These programs have been successful in stopping the increase in extraction rights in water and fish as well as $\mathrm{SO}_{2}$ emissions. This has allowed resource users to manage scarcity and reduce the socio-economic impact of staying within the cap especially for resources with a variable extraction limit such as for water and fisheries. For these resources in jurisdictions such as Australia for water [76] and New Zealand for fisheries $[77,78]$ resource users have both an entitlement to access the resource as well as an annual right to extract. Under such systems the right to extract in a given season might be below the underlying entitlement, by allowing trading in such seasonal extraction rights, actual extraction can move to the most productive and profitable extractors.

A cap-and-trade program with a declining cap has been used with success in the $\mathrm{US} \mathrm{SO}_{2}$ emission trading program $[75,79]$. This is a beneficial approach if the level of extraction or pollution is above sustainable levels at the time it is capped. Resource users can then be granted a right to their current level of extraction/emission. The total cap, and thereby each users entitlement, is then reduced over time until the cap reaches sustainable level. This gives users time to adjust and allows markets to determine who retains extraction/emission and who stops and in the process those suffering reductions are compensated by those retaining their extraction/emission.

\section{CONCLUSIONS}

In this paper we have illustrated that economic incentives and instruments have been used by rulers and governments for at least five thousand years in pursuit of the political, economic and social objectives of the time. These have been quite consistent across the world and have ranged from settlement of colonies, closer settlement of otherwise unattractive areas, settlements of frontier regions for state security, and increasing and intensifying agricultural production as a means of increasing tax revenue. A common denominator throughout history has been that the results of these policies have been serious environmental degradation and in some instances the collapse of whole societies. It was not until the 1960s that the environmental impact of these policies became obvious as the television visualized many of the issues and increased affluence, recreational time and use of the car brought a larger proportion of the population in direct contact with the environment. As a result society's values started to change placing more emphasis on water quality and recreation leading to a shift in public opinion on the environment, and political pressure from special interest groups increased to a level where policy makers started to acknowledge that this development had to change. Consequently, more recently economic instruments have been used to limit or change the way in which we interact with natural resources. Schemes to pay landowners to implement best 
management practices to increase the production of ecosystem services, to purchase water back from irrigators to leave more water for the environment, and to pay farmers to re-vegetate their land or create wetland are being implemented.

Clearly economic incentives have worked when the policy objectives were expansionary. Today policy objectives are changing with increased emphasis on sustainable levels of resource extraction, methods of resource use and environmental outcomes. The objectives of economic incentives are thus changing from encouraging an expansion of resource use to encouraging a contraction. While there are some early indications of success, the verdict is still out whether economic incentives or instruments alone will be successful in facilitating the necessary contraction. Policy makers are faced with a number of challenges in this process and they will have to think outside the box and be innovative in their choice of economic instrument if they are to achieve sustainable development.

Environmental improvement and sustainable development is not only an issue of the level of resource extraction, but also an issue of how these resources are extracted and used. Hence economic instrument have to be designed to transform human behaviour and interaction with natural resources and how to most cost effectively reduce resource use. Consideration also needs to be given to the balance between regulation and economic instruments. Resource users must be under a fundamental duty of care in their use of resources. The pursuit of sustainable development should not rely solely on economic instruments. Conscious decisions need to be made to support the development of transformative innovation, rather than just assume that such innovation will emerge as a by-product of the use of economic instruments.

\section{REFERENCES}

[1] Bjornlund, H. \& Bjornlund, V., Changing societal values: Implications for water management and social opportunities. Water as a Social Opportunity. Queen's Policy Studies Series, eds. J. Linton \& S. Davidson, McGill-Queen's University Press: Montreal, Quebec, Canada, In Press.

[2] Roberts, C., The Unnatural History of the Sea, A Shearwater Book, Published by Island Press: Washington D.C., USA, 2007.

[3] Montgomery, D.R., Dirt. The Erosion of Civilizations, University of California Press: Berkeley California, 2007.

[4] Acheson, J.M., The Lobster Gangs of Maine, University Press of New England: Hanover and London, 1988.

[5] Montgomery, D.R., King of Fish. The Thousand-Year Run of Salmon, Westview Press: USA, 2004.

[6] Kuehne, G. \& Bjornlund, H., Frustration, confusion and uncertainty: Qualitative responses from Namoi valley irrigators. Water, 33(3), pp. 78-82 (the Journal of the Australian Water Association), 2006.

[7] The potential Impact of Trawling. A report prepared by: OCEANS Ltd., Newfoundland for the Newfoundland Inshore Fisheries Association, pp. 79-89, 1990.

[8] Ferne, R.A., Shaykh and Effendi. Changing Patterns of Authority Among the El Shabana of Southern Iraq, Harvard University Press: Cambridge, Massachusetts, 1970.

[9] Healy, M., The Ancient Assyrians, Osprey: London, 1991.

[10] Van De Mieroop, M., The Ancient Mesopotamian City, Clarendon Press: Oxford, 1997.

[11] Sharlack, T., Taxes in the ancient Mesopotamia. University of Pennsylvania Almanac, 48(28), p. 4, 2002.

[12] Tjeerd, H., Van Andel, C., Runnels, K. \& Pope, O., Five thousands years of land use and abuse in the Southern Argolid Greece. Hesperia, 55(1), pp. 103-128, 1986. doi: http://dx.doi. org/10.2307/147733 
[13] Jacobsen, T. \& Adams, R., Salt and silt in ancient Mesopotamian agriculture. Science, 28(3334), pp. 1251-1258, 1958. doi: http://dx.doi.org/10.1126/science.128.3334.1251

[14] Ponting, C., Green History of the World, Vol. 75, Penguin Books: London, England, 2007.

[15] Fussel, G.E., Farming systems of the classical era. Technology and Culture, 8(1), pp. 16-44, 1967. doi: http://dx.doi.org/10.2307/3101523

[16] Balsdon, J., Roman Civilization, Pelican Press: Gretna, Louisiana, USA, 1965.

[17] Cowell, F., Life in Ancient Rome, G.P. Putnam's Sons: New York, 1961.

[18] Barker, G.A., Tale of two Deserts: Contrasting desertification histories on Rome's desert frontiers. World Archaeology, 33(3), Ancient Ecodisasters, pp. 488-507, 2002.

[19] Barker, G.W., Gilbertson, D.D., Jones G.D.B. \& Mattingly D.J., Farming the Desert. The UNESCO Libyan Valleys Archaeological Survey Vol.1: Syntesis (principal editor, G. Barker), Society for Libyan Studies: Paris and London UNESCO, 1996.

[20] Watson, A., The Arab agricultural revolution and its diffusion, 700-1100. The Journal of Economic History, 34(1), pp. 8-35, 1974. doi: http://dx.doi.org/10.1017/S0022050700079602

[21] Golas, P., Rural China in the song. Journal of Asian Studies, 39(2), pp. 291-325, 1980. doi: http://dx.doi.org/10.2307/2054291

[22] Miller, F.P., Economy of the Song Dynasty, Alphascript Publishing: Germany, 2009.

[23] Millward, J.A., "Coming onto the Map": "Western regions" Geography and cartographic nomenclature in the making of Chinese empire in Xinjiang. Late Imperial China, 20(2), pp. 61-98, 1999. doi: http://dx.doi.org/10.1353/late.1999.0008

[24] Sun, J.Z., The Research on Environment and Resources of Inner Mongolia, Inner Mongolia Normal University Press: Huhhot, 1996 (in Chinese. Translation by the assistance of Professor $\mathrm{Xu}$, University of Lethbridge).

[25] Zhao, Songqiao., The Semi-Arid land in Eastern Inner Mongolia - An area of critical environmental change. Chinese Journal of Arid Land Research, 3(3), pp. 257-271, 1990.

[26] Batjargal, Z., Desertification in Mongolia. RALA REPORT NO. 200. Proceedings from the International Workshop on Rangeland Desertification, (held in Iceland) Documenting Rangeland Desertification, 1997.

[27] Liu, J. \& Diamond, J., China's environment in a globalizing world. Nature, 435, pp. 1179-1186, 2005. doi: http://dx.doi.org/10.1038/4351179a

[28] Nitz, H.-J., The Church as colonist: the Benedictine Abbey of Lorch and planned Waldhufen colonization in the Odenwald. Journal of Historical Geography, 9, pp. 105-123, 1983. doi: http://dx.doi.org/10.1016/0305-7488(83)90218-9

[29] Bentley, J. \& Ziegler, H., Traditions and Encounters, McGraw-Hill: Boston, 2003.

[30] Ekelund, R.B. \& Tollison, R.D., Mercantilist origins of the corporation. The Bell Journal of Economics, 11(2), pp. 715-720, 1980. doi: http://dx.doi.org/10.2307/3003390

[31] Harris, C.R., The Reluctant Land: Society, Space, and Environment in Canada before Confederation, UBC Press: University of British Columbia, Vancouver BC, 2008.

[32] Newson, L., Indian population patterns in colonial Spanish America. Latin American Research Review, 20(3), pp. 74-74, 1985.

[33] Lowdermilk, W.C., Conquest of the land through seven thousand years, available at http:// journeytoforever.org/farm_library/Lowd/Lowd3.html.

[34] Butler, J., British convicts shipped to American colonies. American Historical Review, 2, pp. 12-33, 1896. doi: http://dx.doi.org/10.2307/1833611

[35] Egan, T., The Worst Hard Time: The Untold Story of Those Who Survived the Great American Dust Bowl, Mariner Books: USA, 2006.

[36] Ganoe, J.T., The beginnings of irrigation in the United States. The Mississippi Valley Historical Review, 25(1), pp. 59-78, 1938. doi: http://dx.doi.org/10.2307/1892325 
[37] Worster, D., Rivers of Empire: Water, Aridity, and the Growth of the American West. Pantheon: New York, 1985.

[38] Morton, A., History of Prairie Settlement and "Dominion Lands" Policy, Macmillan Toronto: Ontario, 1938.

[39] Hughes, R., The Fatal Shore, Pan: London, 1988.

[40] Bumsted, S., Arrival and Settlement. In the Encyclopedia of Canada's Peoples, available at www.multiculturalcanada.ca/Encyclopedia/A-Z/s2/5.

[41] La Croix, S., Sheep, squatters, and the evolution of land rights in Australia: 1787-1847. Proceeding of the 3rd Annual Conference of the International Association for the Study of Common Property, Washington DC, 1992.

[42] Edwards, I.E., The 1820 Settlers in South Africa, Longmans: London, 1934.

[43] Bryer, L. \& Hunt, K., The 1820 Settlers, Don Nelson: Cape Town, 1984.

[44] Glanzing, A., Native Vegetation Clearance, Habitat Loss and Biodiversity Decline: An Overview of Recent Native Vegetation Clearance in Australia and its Implications for Biodiversity Decline, Department of the Environment Sport and Territories: Canberra, 1995.

[45] Nick, A. \& Langston, A., Evolution of a Social-ecological System: Adaptation and Resilience in New South Wales Rangelands 1850 to 2020, available at www.cse.csiro.au/research/ nswrangelands/pubs/.../Draft_Paper.pdf.

[46] Rutherford, J., Interplay of American and Australian ideas for development of water projects in Northern Victoria. Annals of the Association of American Geographers, 54(1), pp. 88-106, 1964. doi: http://dx.doi.org/10.1111/j.1467-8306.1964.tb00476.x

[47] Powel, R.A., Watering the Garden State, Water, Land and Community in Victoria 1834-1988, Allan and Unwin: Sydney, 1989.

[48] Bjornlund, H., Can water markets assist irrigators managing increased supply risk? Some Australian experiences. Water International, 31(2), pp. 221-232, 2006. doi: http://dx.doi.org/ $10.1080 / 02508060.2006 .9709672$

[49] D'Souza, R., Supply-side hydrology in India. Economic and Political Weekly, 38(36), pp. 3785-3790, 2003.

[50] Mosse, D., Colonial and contemporary ideologies of "Community Management": the case of tank irrigation development in South India. Moderns Asian StudiesI, 33(2), pp. 303-338, 1999. doi: http://dx.doi.org/10.1017/S0026749X99003285

[51] Meinzen-Dick, R.S., Local Management of Tank Irrigation in South India: Organization and Operation, Cornell Studies in Irrigation No 3, Cornell University: New York, N.Y., USA, 1984.

[52] Hardiman, D., The politics of water in colonial India. Journal of South East Studies, 25(2), pp. 111-120, 2002.

[53] McGinn, P., Capital, 'Development' and Canal Irrigation in Colonial India, Working paper 209. Institute for Social and Economic Change.

[54] Fan, S. \& Gulati, A., Investment, Subsidies, and Pro-Growth in Rural India, IFPRI Discussion Paper 00716, International Food Policy Research Institute: Washington D.C., 2007.

[55] Shive, V., The Violence of the Green Revolution, Zed Books: London and New York, 1991.

[56] The Economist When the rain fails, published on 10 September 2009, available at www. economist.com/node/14401149.

[57] Economic Research Service; Briefing Rooms: India Policy, available at http://www.ers.usda. gov/briefing/india/policy.htm.

[58] Stavins, R.N., What can we learn from the grand policy experiment? Lessons for SO2 allowance trading. Journal of Economic Perspective, 12(3), pp. 69-88, 1998. doi: http://dx.doi. org/10.1257/jep.12.3.69 
[59] Scott, A., The Fishery: the objective of sole ownership. The Journal of Political Economy, 63, pp. 116-124, 1955. doi: http://dx.doi.org/10.1086/257653

[60] Welch, W., The political feasibility of full ownership property rights: the cases of pollution and fisheries. Policy Sciences, 16, 165-180, 1983. doi: http://dx.doi.org/10.1007/BF00138349

[61] Runolfsson, B., ITQs in Iceland: Their Nature and Performance. Individual Transferable Quotas in Theory and Practice, eds. R. Arnason \& H.H. Gussurarson, The University of Island Press: Reykjavik, pp. 103-140, 1999.

[62] Major, P., The evolution of ITQs in New Zealand. Individual Transferable Quotas in Theory and Practice, eds. R. Arnason \& H.H. Gussurarson, The University of Island Press: Reykjavik, pp. 15-30, 1999.

[63] Bjornlund, H. \& McKay, J., Aspects of water markets for developing countries - experiences from Australia, Chile and the US. Journal of Environment and Development Economics, 7(4), pp. 767-793, 2002.

[64] Randall, A. \& Taylor, M.A., Incentive-based solutions to agricultural environmental problems: recent developments in theory and practice. Journal of Agricultural and Applied Economics, 32(2), pp. 221-234, 2000.

[65] James, D., Economic Incentives - Australian Experience with Economic Instruments to Environmental Management, Environment Australia: Canberra, 1997.

[66] O'Shea, H., Collins, D., Davies, S. \& Smith, S., Tradable quota design - lessons learned. Outlook, 97, pp. 116-122, 1997.

[67] Bueren, M., v Emerging Markets for Environmental Services. Implications and Opportunities for Resource Management in Australia. Joint Venture Agroforestry Program, Rural Industries Research and Development Corporation: Kingston ACT, 2001.

[68] Murtough, G., Aretino, B. \& Matysek, A., Creating Markets for Ecosystem Services, Staff Research paper. Productivity Commission: Melbourne, 2002.

[69] Wossink, A., The Dutch Nutrient Program - Past experience and lessons for the future. Paper prepared for a workshop on Ex-post tradable permit evaluation for the National Policies Division, Environment Directorate. Paris: OECD, 2003.

[70] Wheeler, S., Garrick, D., Loch, A. \& Bjornlund, H., (in press a): Evaluating alternative water market products to acquire water for the environment in Australia. Land Use Policy, 30, pp. 427-436, 2012. doi: http://dx.doi.org/10.1016/j.landusepol.2012.04.004

[71] Wheeler, S., Zuo, A., Bjornlund, H. \& Lane Miller, C., Selling the farm silver? Understanding water sales to the Australian government. Journal of Environment and Resource Economics, 52(1), pp. 133-154, 2011. doi: http://dx.doi.org/10.1007/s10640-011-9523-5

[72] Drury, R., Belliveau, M., Kuhn, J. \& Bansal, S., Pollution trading and environmental injustice: Los Angeles' failed experiment in air quality policy. Duke Environmental. Law and Policy Forum, 9, pp. 231-265, 1999.

[73] Shabman, L., Compensating for the impacts of wetland fill: The US experience with credit sales. Paper prepared for a workshop on Ex-post tradable permit evaluation for the National Policies Division, Environment Directorate. OECD: Paris, 2003.

[74] Hayes, R., The Basics of Carbon Trading. NewZealand Forest Industry, 31(11), pp. 14-17, 2000.

[75] Colby, B., Cap-and-trade policy challenges: a tale of three markets. Land Economics, 76(4), pp. 638-658, 2000. doi: http://dx.doi.org/10.2307/3146957

[76] Bjornlund, H., Wheeler, S. \& Cheesman, J., Irrigators, water trading, the environment and debt: Perspectives and realities of buying water entitlements for the environment. Basin Futures: Water Reform in the Murray-Darling Basin, eds. D. Connell \& Q. Grafton, The Australian National University E Press, Canberra: Australia, pp. 291-302, 2011. 
[77] Edwards, M., Catch against quota - a revised approach. Outlook, 91, pp. 123-134, 1997.

[78] Kerr, S., Newell, R. \& Sanchirico, J., Evaluating the New Zealand Individual Transferable Quota Market for Fisheries Management. Paper prepared for a workshop on Ex-post tradable, 2003.

[79] Ellerman, A., The U.S. SO2 Cap-and-Trade program. Paper prepared for a workshop on Ex-post tradable permit evaluation for the National Policies Division, Environment Directorate. OECD: Paris, 2003. 